\title{
Sources of Tyrosine in Genotypes of Solanum tuberosum L. Differing in Capacity to Produce Melanin Pigments
}

\author{
Robert P. Sabba and Bill B. Dean ${ }^{1}$ \\ Department of Horticulture and Landscape Architecture, Irrigated Agriculture Research and Extension \\ Center, Washington State University, Prosser, Rt. 2, Box 2953-A, Prosser, WA 99350
}

Additional index words. blackspot, proteinase, chorismate mutase, bruise, potato

\begin{abstract}
Potato tubers (Solanum tuberosum) of genotypes that vary in resistance to dark pigment formation when damaged, characteristic of the physiological disorder blackspot, were assayed for free tyrosine. The tubers were also assayed for relative levels of chorismate mutase and proteinase activities, which can regulate free tyrosine levels. The susceptibility of potato tubers to blackspot was shown to be correlated to the amount of free tyrosine by third order regression $(R=\mathbf{0 . 8 8})$. Tyrosine was found to be a limiting factor in pigment development. Chorismate mutase activity (CMI and CMII) was not correlated to blackspot susceptibility of the genotypes studied. Proteinase activities of Atlantic, TXA 763-5, Ranger Russet, Russet Burbank, and Lemhi Russet tuber protein extracts measured with synthetic substrates correlated with blackspot susceptibility. This suggests that the high free tyrosine levels associated with blackspot susceptibility may be due to high levels of proteinase activity in the tuber, rather than tyrosine synthesis.
\end{abstract}

Solanum tuberosum tubers used commercially for a variety of consumer products are subjected to bruising during harvesting and handling. If tubers are bruised by dropping them onto hard surfaces, they may develop discolored areas referred to as blackspot bruise. The blackspot bruise is an accumulation of melanin-like pigments (Van Middelem et al., 1953) formed by oxidation of phenolic substrates by polyphenyloxidase (PPO) (Matheis, 1987a). The principle substrates for PPO in potato tubers are tyrosine and chlorogenic acid (Craft, 1966; Matheis, 1987b; Patil and Zucker, 1965). Susceptibility to blackspot bruise may be influenced by cultural practices, including irrigation and mineral nutrition (Kunkel and Gardner, 1965; Mapson et al., 1963; Mulder, 1949). Susceptibility also varies between different cultivars/genotypes and is correlated with endogenous-free tyrosine concentrations in the tuber ( Corsini et al., 1992; Dean et al., 1993; Mapson et al., 1963; Sapers et al., 1989; Stark et al., 1985; Tripathi et al., 1983). Blackspot bruise susceptibility does not correlate with chlorogenic acid or other phenolic components in the tuber ( Corsini et al., 1992; Dean et al., 1993; Mapson et al, 1963).

The amount of tyrosine available for oxidation by PPO depends on tyrosine synthesis and its partitioning into protein (Dean et al., 1992). Tyrosine is synthesized via the shikimic acid pathway (Gilchrist and Kosuge, 1980), which is believed to be regulated by several key enzymes (Jensen, 1986). One such enzyme is chorismate mutase (CM), of which two isozymes (CMI and CMII) have been characterized (Gilchrist et al., 1972; Goers and Jensen, 1984; Kuroki and Conn, 1988; Singh et al., 1986).

The quantity of tyrosine found in the free, readily oxidizable pool may also be affected by the relative rates of protein synthesis and degradation. Since potato cultivars vary considerably in protein content and protein content has been correlated with blackspot resistance (Corsini et al., 1992; Stark et al., 1985), the levels of

Received for publication 22 Feb. 1993. Accepted for publication 3 Sept. 1993. Hort/ LA Paper No. 92-14. Project No. 4002. College of Agriculture and Home Economics Research Center, Washington State University, Pullman, WA 99164. This work was supported by the National Potato Council (U.S. Dept. of Agriculture), Grant No. 58-5366-1-140. The cost of publishing this paper was defrayed in part by the payment of page charges. Under postal regulations, this paper therefore must be hereby marked advertisement solely to indicate this fact.

${ }^{1}$ To whom correspondence should be sent. proteinase activity may be important in tyrosine availability and subsequently blackspot resistance. It is important to understand how tyrosine synthesis and partitioning contribute to the soluble pool of tyrosine in potato tubers. Since our previous work indicated that the amount of protein decreased at the same time as free tyrosine and pigment formation increased (Dean et al., 1993), we decided to look at protein hydrolysis as a potential source of tyrosine. The purpose of this report is to examine the relative activities of chorismate mutase and proteinase activity in resistant and susceptible potato genotypes.

\section{Materials and Methods}

Potato tuber production in the field. Potato tubers from 14 cultivars varying in blackspot susceptibility were obtained from the U.S. Dept. of Agriculture (USDA) breeding program at Aberdeen, Idaho. The cultivars were genotypes selected from a diallel used to examine the heritability of blackspot susceptibility (Table 1) (Dean et al., 1993; Pavek et al., 1993). The tubers were stored briefly at $2 \mathrm{C}$ until needed for tyrosine determinations. The basal end of each tuber $(\approx 10$ to $20 \%$ the length of the tuber) was removed for blackspot susceptibility and tyrosine analysis.

A second group of five cultivars was selected based on their bruise susceptibility and grown for the purpose of enzyme assays. This group consisted of Russet Burbank, Lemhi Russet, Atlantic, Ranger Russet, and TXA 763-5. They were planted in early April at Washington State University, Prosser, Irrigated Agriculture Research and Extension Center (IAREC) and grown using standard commercial production practices. All the plants were harvested following maturation (vine senescence) and placed in storage at $2 \mathrm{C}$ briefly until the assays were conducted. The average tuber size varied by cultivar so average-sized tubers were selected from each cultivar.

Blackspot susceptibility measurement. The susceptibility of tuber tissue to blackspot development was determined by homogenizing half of the basal portion of the tuber $\approx 10$ to $20 \%$ of the tuber) according to the homogenization procedure outlined previously (Dean et al., 1993). Between 20 and $50 \mathrm{~g}$ of tuber tissue was homogenized with $2 \mathrm{x}$ v/w $0.05 \mathrm{~m}$ phosphate buffer, $\mathrm{pH} 6.5$, and allowed to oxidize for $24 \mathrm{~h}$ at room temperature. The oxidized 
Table 1. Cultivars from the U.S. Dept. of Agriculture breeding program at Aberdeen. $\mathrm{OD}_{475}$ of control homogenates and endogenous-free tyrosine levels are provided for each cultivar. Each value represents the mean of three replicates \pm SE.

\begin{tabular}{lcc}
\hline \hline Genotype & $\mathrm{OD}_{475}$ & Free tyrosine $\left(\mu \mathrm{g} \cdot \mathrm{g}^{-1}\right)$ \\
\hline A84685-14 & $0.147 \pm 0.013$ & $71.9 \pm 6.2$ \\
A84707-16 & $0.155 \pm 0.039$ & $79.5 \pm 4.6$ \\
TXA 763-5 & $0.165 \pm 0.031$ & $63.0 \pm 4.5$ \\
A7938-1 & $0.340 \pm 0.045$ & $90.0 \pm 5.2$ \\
A75188-3 & $0.371 \pm 0.070$ & $113.9 \pm 3.7$ \\
A7816-14 & $0.387 \pm 0.046$ & $112.0 \pm 5.7$ \\
875PX15-1 & $0.456 \pm 0.087$ & $196.4 \pm 36.3$ \\
A84727-60 & $0.470 \pm 0.108$ & $161.7 \pm 7.0$ \\
A81473-2 & $0.523 \pm 0.080$ & $189.2 \pm 16.0$ \\
Belrus & $0.531 \pm 0.046$ & $229.5 \pm 16.0$ \\
Norchip & $0.690 \pm 0.121$ & $273.9 \pm 38.1$ \\
A84537-42 & $0.710 \pm 0.073$ & $220.8 \pm 11.5$ \\
Lemhi Russet & $0.755 \pm 0.032$ & $172.5 \pm 18.7$ \\
Russet Burbank & $0.856 \pm 0.109$ & $374.0 \pm 60.2$ \\
ATD 63-7 & $0.962 \pm 0.175$ & $236.0 \pm 18.5$ \\
\hline
\end{tabular}

homogenate was filtered and centrifuged, and the optical density of the supernatant was measured at $475 \mathrm{~nm}$. The second half of the basal end of the tuber was frozen at $-80 \mathrm{C}$ for either tyrosine analysis or protein extraction for enzyme assays. Each sample consisted of three randomly selected tubers and was replicated four times.

Tyrosine analysis. The frozen tuber tissues obtained from the U.S. Dept. of Agriculture breeding program samples were lyophilized to dryness with a Freezmobile (model 125L; Vertis Co., Gardner, N.Y.), ground with a Wiley Mill (Arthur Thomas Co., Philadelphia), and passed through a 40-mesh screen. The dry, ground samples were further powdered with a 'Wig-L-Bug' powderer (Crescent Dental Manufacturing Co., Chicago) for extraction. The samples were extracted and analyzed by high-performance liquid chromotography (HPLC) using the 'Pico Tag' procedure as previously reported (Dean et al., 1993).

Substrate additions. A subsample of six genotypes with varying amounts of free tyrosine was selected to measure the effect of exogenously added tyrosine on total oxidation of homogenized potato tuber tissue. Samples were assayed to determine endogenousoxidative enzyme (PPO) substrate. These measurements were also used to determine if PPO activity was limiting blackspot pigment formation. The subsample was selected from the U.S. Dept. of Agriculture breeding program samples (Lemhi Russet, TXA 763-5, A75188, 875PX15, A84531, and A84727). Between 50 and $75 \mathrm{~g}$ of basal end tuber tissue from each genotype was homogenized with $2 \mathrm{x}$ v/w $0.05 \mathrm{~m}$ phosphate buffer, $\mathrm{pH} 6.5$. The homogenate was then filtered through filter paper (Whatman No. 1; Hillsboro, Ore.) and centrifuged at 13,220 g for $10 \mathrm{~min}$. Tyrosine was added to the supernatants at 0 or $400 \mu \mathrm{g}$ per gram fresh weight of potato tissue. The homogenates were then allowed to oxidize overnight at room temperature. The increase in pigment formation over the control (without added tyrosine) was measured spectrophotometrically at $475 \mathrm{~nm}$.

Protein extraction for enzyme assays. Half of the basal portions of two to four tubers from each 1992 field harvest genotype was removed, placed in a plastic zip-lock bag, and frozen immediately at $-80 \mathrm{C}$. Four replicate samples from each treatment were collected. The frozen sample was diced and $5.0 \mathrm{~g}$ of the sample was homogenized in a cold mortar with $20 \%$ insoluble polyvinyl-polypyrrolidone (PVP) in $30 \mathrm{ml}$ cold $0.1 \mathrm{~m}$ phosphate buffer, $\mathrm{pH} 6.5$, containing $5 \mathrm{~mm}$ dithioerythritol (DTE). The homogenized tissue was then transferred to a $40-\mathrm{ml}$ glass tissue grinder with $10 \mathrm{ml}$ cold buffer for final homogenization. The homogenate was centrifuged at $29,000 \mathrm{~g}$ for $20 \mathrm{~min}$ at $6 \mathrm{C}$. Proteins in the supernatant were precipitated with ammonium sulfate at $85 \%$ saturation with stirring for $20 \mathrm{~min}$. The samples were centrifuged for $20 \mathrm{~min}$ at 29,000 $\mathrm{g}$ to obtain the protein pellet. The final pellet was resuspended in $5 \mathrm{ml}$ cold $0.05 \mathrm{M}$ phosphate buffer, $\mathrm{pH} 6.5$ containing $1 \mathrm{~mm}$ DTE. The samples were then desalted by passing them through a column (model Sephadex G-25; Pharmacia Inc., Alameda, Calif.) with the same buffer. All procedures were carried out at $6 \mathrm{C}$. The final extract represented $0.71 \mathrm{~g} \cdot \mathrm{ml}^{-1}$ and all results are presented on a fresh-tissue-weight basis. This protein extract was used in the proteinase and chorismate mutase assays.

Chorismate mutase assay. The assay mixture for total chorismate mutase activity (CMI + CMII) contained $200 \mu$ protein extract, $100 \mu \mathrm{l} 0.1 \mathrm{~m}$ phosphate buffer, $\mathrm{pH} 7.0,100 \mu \mathrm{l} 2 \mathrm{~mm}$ chorismic acid (dissolved in $0.1 \mathrm{~m}$ phosphate buffer, $\mathrm{pH} 7.0$ ) and $100 \mu \mathrm{l} 1 \mathrm{~mm}$ L-tryptophan. The final concentrations were $400 \mu \mathrm{M}$ for chorismic acid and $200 \mu \mathrm{M}$ for L-tryptophan. Activity of the unregulated isozyme CMII was measured by substituting $100 \mu \mathrm{l}$ buffer for tryptophan. The difference between these two activities was taken as the CMI activity (Singh et al., 1986). The reaction mixture was incubated for $20 \mathrm{~min}$ at $25 \mathrm{C}$ after which it was terminated by addition of $100 \mu \mathrm{l} 6 \mathrm{~N} \mathrm{HCl}$. The samples were incubated at room temperature for $10 \mathrm{~min}$ to convert prephenate to phenyl-pyruvate followed by addition of $400 \mu \mathrm{l} 4 \mathrm{~N} \mathrm{NaOH}$. The absorption of phenyl-pyruvate was measured at $320 \mathrm{~nm}$ with $1 \mathrm{~N} \mathrm{NaOH}$ as a reference (Kuroki and Conn, 1988; Singh et al., 1986). All results were expressed on a fresh-weight basis so that approximate in vivo activities could be compared between genotypes with widely different protein and dry-matter concentration.

$N$-Benzoyl-L-arginine p-nitroanilide (L-BAPNA) endopeptidase assay. A 200- $\mu$ l aliquot of each sample protein extract was added to $250 \mu \mathrm{l}$ of $0.1 \mathrm{M}$ phosphate buffer, $\mathrm{pH} 7.0$, and $50 \mu 12 \mathrm{~mm}$ L-BAPNA [dissolved in $20 \%$ dimethylformamide (DMF)]. Control samples containing either no substrate or no extract were also assayed. The final concentration of L-BAPNA was $200 \mu \mathrm{M}$. The samples were incubated for $40 \mathrm{~min}$ at $30 \mathrm{C}$ after which the reactions were terminated with $500 \mu \mathrm{l} 30 \%$ acetic acid. Absorbance was measured at $405 \mathrm{~nm}$ according to Santarius and Belitz, 1978. The activity is expressed as nmoles p-nitroaniline $\mathrm{g}^{-1} \cdot \mathrm{min}^{-1}$.

L-Phenylalanine-2-naphthylamide (L-Phe-NA) aminopeptidase assay. Aminopeptidase activity utilizing the L-Phe-NA substrate was determined by adding $100 \mu \mathrm{l}$ protein extract to $500 \mu 10.1$ M phosphate buffer, pH 7.0, and $200 \mu 11 \mathrm{~mm}$ L-Phe-NA (dissolved in $20 \%$ DMF). The final concentration of L-Phe-NA was $250 \mu \mathrm{M}$. The mixture was incubated for $30 \mathrm{~min}$ at $30 \mathrm{C}$, after which it was terminated by adding $200 \mu 150 \%$ trichloroacetic acid (TCA). The protein was pelleted by centrifugation for $10 \mathrm{~min}$ at $16,000 \mathrm{~g}$ after precipitation for $20 \mathrm{~min}$ at 4C (Waters and Dalling, 1979). The enzymatic product was measured after diazotization by incubating the supernatant with $1 \mathrm{ml} 0.1 \% \mathrm{NaNO}_{2}$ for $3 \mathrm{~min}$ followed by incubation with $0.5 \%$ ammonium sulfamate for $2 \mathrm{~min}$, after which $2 \mathrm{ml} 0.05 \% \mathrm{~N}$-naphythylethylenediamine (in 95\% ethanol) was added. The absorption by the azo-dye reaction product was measured at $540 \mathrm{~nm}$ after $15 \mathrm{~min}$ (Blackwood and Mandl, 1961). The results were expressed as nmoles 2-naphthylamine $\mathrm{g}^{-1} \cdot \mathrm{min}^{-1}$.

L-Lysine-2-naphthylamide (L-Lys-NA) aminopeptidase assay. The reaction mixture consisted of $150 \mu \mathrm{l}$ protein extract, $550 \mu \mathrm{l}$ $0.1 \mathrm{M}$ Tris- $\mathrm{HCl}$ buffer ( $\mathrm{pH} 8.0$ ) and $100 \mu \mathrm{l} 2 \mathrm{~mm}$ L-Lys-NA (dissolved in hot $\mathrm{H}_{2} \mathrm{O}$ ). The final concentration of L-Lys-NA was $250 \mu \mathrm{M}$. The assay conditions and determination of activity are the same as for the L-Phe-NA reported above. 


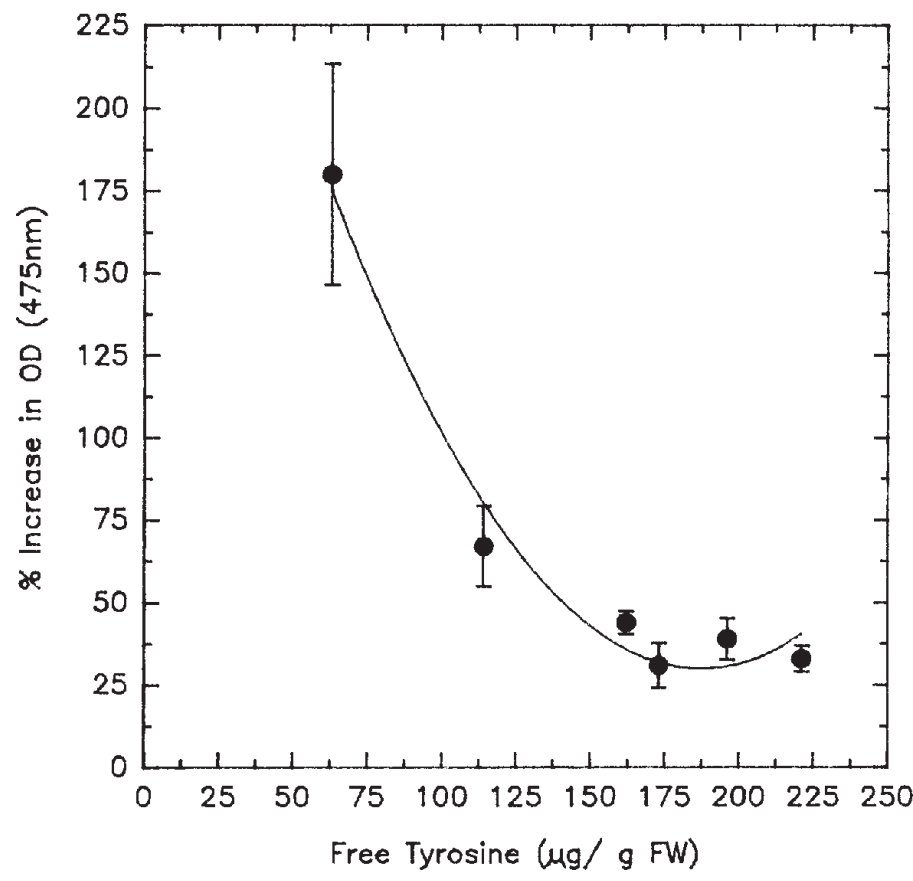

Fig. 1.The percent increase in optical density $\left(\mathrm{OD}_{475}\right)$ of crude tissue homogenates with additions of $400 \mu \mathrm{g}$ tyrosine/g tissue compared to the level of endogenous free tyrosine. The values plotted are means of three replications \pm SE. Cultivars used are listed in Methods.

\section{Results}

Pigment development in tuber tissues. The amount of tyrosine in the soluble fraction of extracts from potato tubers from the U.S. Dept. of Agriculture breeding program correlated positively and significantly by third order regression $\left(90.06-356.59 x+2000 x^{2}\right.$ $-1000 x^{3}$ ) with the susceptibility of homogenized tuber tissue to pigment development measured by optical density at $475 \mathrm{~nm}(r=$ 0.88 ). Table 1 lists the cultivars used in this experiment, with their $\mathrm{OD}_{475}$ and free tyrosine levels. The percent increase in OD at 475 $\mathrm{nm}$ when tyrosine was added to homogenates from the six cultivars selected from the USDA breeding program at $400 \mu \mathrm{g} \cdot \mathrm{g}^{-1}$ equivalents was largest with cultivars that were lowest in endogenousfree tyrosine (Fig. 1). The percent increase in $\mathrm{OD}_{475}$ decreased with increasing endogenous free tyrosine until it reached a saturation point between 162 and $225 \mu \mathrm{g} \cdot \mathrm{g}^{-1}$ tyrosine. The percent increase at this saturation level was $\approx 30 \%$ with $400 \mu \mathrm{g} \cdot \mathrm{g}^{-1}$ added tyrosine.

Chorismate mutase (CM) activity. The chorismate mutase activities of protein extracts from the five cultivars grown at the IAREC are shown in Table 2. There was no significant difference in CMI, CMII, or total CM activity measured from extracts of susceptible cultivars compared to resistant cultivars. There was no significant correlation between blackspot susceptibility (as deter-

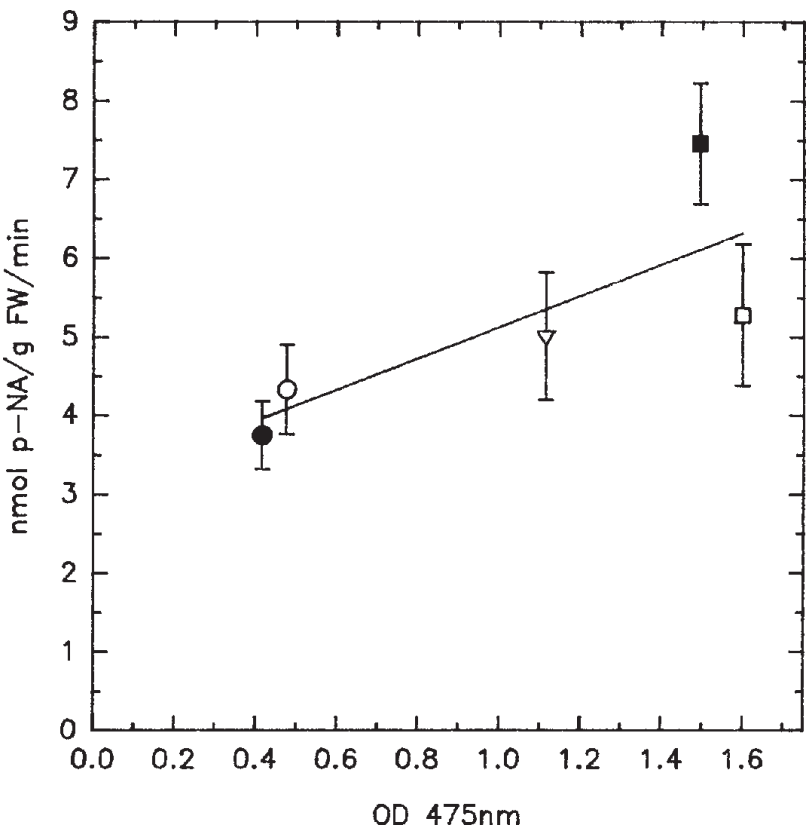

Fig. 2.The rate of endopeptidase activity from blackspot susceptible and resistant cultivars measured with L-BAPNA as the substrate compared to the OD (475) of homogenate solutions from the following blackspot susceptible and resistant potato cultivars: Atlantic $(\bullet)$, TXA 763-5 (○), Ranger Russet ( $\nabla)$, Lemhi Russet $(\square)$, and Russet Burbank $(\square)$. The values plotted are the means of four replications \pm SE.

mined by the $\mathrm{OD}_{475}$ of the homogenate) and CM activity ( $\left.r=0.13\right)$.

Proteinase activity. The endopeptidase activity measured by use of L-BAPNA as substrate correlated positively with the blackspot susceptibility of the genotype $(r=0.78)$ (Fig. 2). The endopeptidase activity determined from Atlantic and TXA 763-5 tuber tissue extracts was $45 \%$ of the activity from Lemhi Russet tubers, but not significantly different from Russet Burbank or Ranger Russet. The aminopeptidase activity was measured with two substrates, L-Phe-NA and L-Lys-NA (Fig. 3). The enzyme activity measured with L-Phe-NA as substrate was $400 \%$ greater than the rate with L-Lys-NA and about $1400 \%$ greater than the endopeptidase activity with L-BAPNA. The aminopeptidase activity measured with L-Phe-NA correlated positively with the blackspot susceptibility of the cultivars $(r=0.92)$. The aminopeptidase activity utilizing L-Lys-NA as the substrate did not correlate positively with blackspot susceptibility.

\section{Discussion}

The propensity of potato tuber tissue to develop dark-colored melanin-like pigments was highly correlated to the amount of endogenous-free tyrosine in the tissue. The total amount of pigment produced seems to be related to the concentration of soluble

Table 2. Chorismate mutase activity for protein extracts derived from five different cultivars. Values represent the means of four replicates $\pm \mathrm{SE}$, and are compared to the mean $\mathrm{OD}_{475} \pm \mathrm{SE}$ of the corresponding homogenate. Those values with the same superscript letter in a column are not different by independent $t$ test (LSD) at the 0.05 level. $P<0.01$.

\begin{tabular}{lccrr}
\hline \hline Cultivar & \multicolumn{1}{c}{ OD $_{475}$} & CMI & CMII & Total CM \\
\hline Atlantic & $0.415 \pm 0.42^{\mathrm{a}}$ & $5.05 \pm 0.65^{\mathrm{ab}}$ & $5.55 \pm 0.56^{\mathrm{b}}$ & $10.60 \pm 0.35^{\mathrm{b}}$ \\
TXA 763-5 & $0.475 \pm 0.023^{\mathrm{a}}$ & $4.32 \pm 0.40^{\mathrm{a}}$ & $4.41 \pm 0.47^{\mathrm{b}}$ & $8.73 \pm 0.82^{\mathrm{b}}$ \\
Ranger Russet & $1.114 \pm 0.116^{\mathrm{b}}$ & $7.85 \pm 0.52^{\mathrm{c}}$ & $8.72 \pm 1.51^{\mathrm{c}}$ & $16.56 \pm 1.30^{\mathrm{c}}$ \\
Lemhi Russet & $1.494 \pm 0.243^{\mathrm{c}}$ & $6.62 \pm 0.60 \mathrm{C}^{\mathrm{bc}}$ & $3.79 \pm 0.24^{\mathrm{ab}}$ & $10.41 \pm 0.41^{\mathrm{b}}$ \\
Russet Burbank & $1.599 \pm 0.182^{\mathrm{c}}$ & $4.24 \pm 0.74^{\mathrm{a}}$ & $1.91 \pm 0.40^{\mathrm{a}}$ & $6.15 \pm 0.85^{\mathrm{a}}$ \\
\hline
\end{tabular}




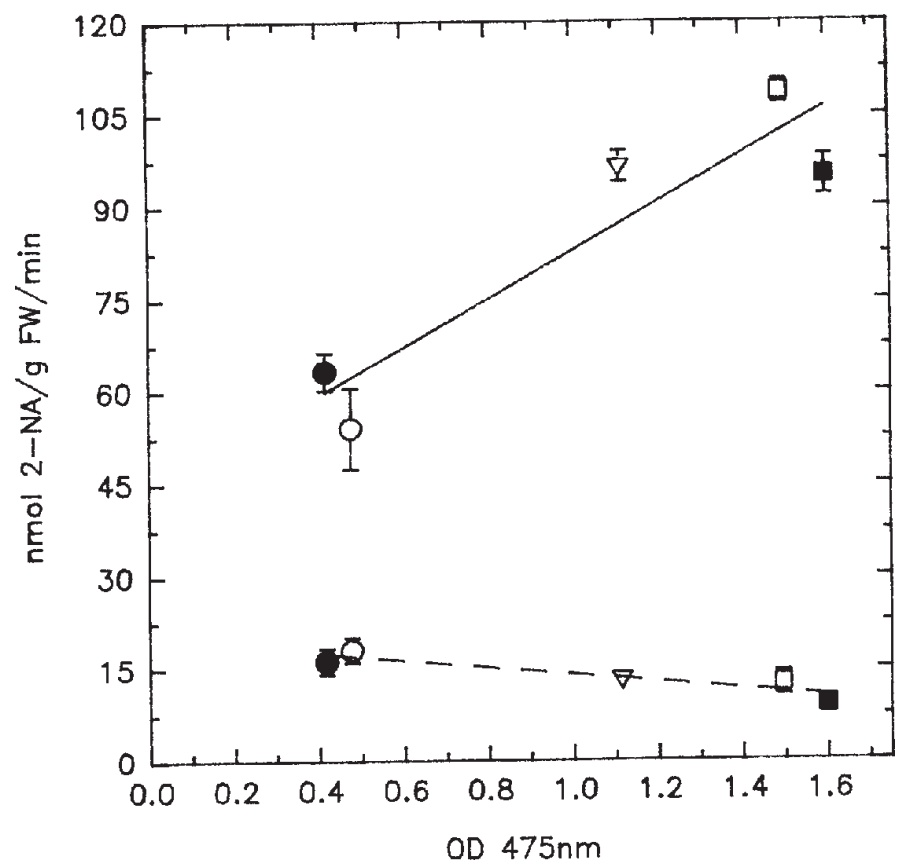

Fig. 3.The rate of aminopeptidase activity from blackspot resistant and susceptible cultivars using L-Phe-NA (-) and L-Lys-NA (----) as substrate compared to the OD (475) of homogenate solutions from blackspot susceptible and resistant potato cultivars. The values plotted are the means of four replications SE. The following cultivars are represented: Atlantic ( ), TXA 763-5 (○), Ranger Russet $(\nabla)$, Lemhi Russet ( $\square)$, and Russet Burbank ( $\square)$.

tyrosine in a quadratic fashion (Table 1). Corsini et al. (1992) showed a linear correlation between endogenous free tyrosine and blackspot susceptibility measured by an abrasive peel method.

Polyphenyloxidase is believed to be the enzyme that catalyzes the conversion of phenolic compounds into the melanin-like pigments responsible for blackspot (Matheis, 1987a). Oxidase activity (presumably PPO) was not a limiting factor in the production of melanin-like pigments from tyrosine in this study (Fig. 1). Addition of $400 \mu \mathrm{g}$ tyrosine/g tissue resulted in an increase of at least $31 \%$ for the $\mathrm{OD}_{475}$ of tuber homogenates, even for the cultivars most susceptible to blackspot (Lemhi Russet and A84531). For the most resistant cultivar, TXA 763-5, the $\mathrm{OD}_{475}$ increased by $180 \%$ when tyrosine was added. The increase in $\mathrm{OD}_{475}$ was most pronounced for cultivars with low endogenous-free tyrosine levels. This demonstrates that the substrates such as tyrosine are the primary limiting factor in pigment production, not PPO activity. This is in agreement with results reported by Weaver et al. (1970) that there was no relationship between PPO activity and blackspot in Russet Burbank tuber tissue.

The in vitro amount of activity of one of the key enzymes in tyrosine synthesis, chorismate mutase, does not explain why the free tyrosine concentration is higher in the susceptible cultivars than the resistant cultivars (Table 2). Therefore, our previous finding that incorporation of 14C-labeled shikimic acid into free tyrosine is greater in Lemhi Russet than TXA 763-5 (Dean et al., 1992) cannot be explained by differences in chorismate mutase activity between the cultivars.

The activity of proteinases in the blackspot resistant cultivars (TXA 763-5 and Atlantic) is lower than the susceptible cultivars (Ranger Russet, Lemhi Russet, and Russet Burbank) with the endopeptidase substrate (Fig. 2) and one of the two aminopeptidase substrates tested (L-Phe-NA, Fig. 3). This is significant, since aminopeptidase activity with L-Phe-NA was greater than any other substrate tested. The relative activity of these proteinases may at least in part explain why the protein-bound tyrosine content in TXA 763-5 is usually 1.5 to 2 times higher than that of Lemhi Russet and Russet Burbank (Corsini et al., 1992).

Previous results showed that ${ }^{14} \mathrm{C}$-Shikimic acid incorporation into free tyrosine is $50 \%$ greater in Lemhi Russet tuber discs compared to TXA 763-5 (Dean et al., 1992). Table 2 shows that chorismate mutase activity is not responsible for the greater free tyrosine production in Lemhi Russet, nor for the greater concentrations of free tyrosine prevalent in susceptible cultivars.

The endopeptidase activity (measured with the substrate L-BAPNA) in the blackspot resistant cultivars was lower than in the susceptible cultivars, especially Lemhi Russet. The aminopeptidase activities of the susceptible cultivars measured with L-Phe-NA was $\approx 70 \%$ greater than the resistant cultivars. Therefore, the relative amounts of tyrosine found in the soluble pool from potato tuber tissue that can be used as a substrate by PPO. The amount of potential protein hydrolysis by endogenous proteinase correlates well with the blackspot susceptibility (melanin-like pigment formation) of cultivars used in this study.

\section{Literature Cited}

Blackwood, C. and I. Mandl. 1961. An improved test for the quantitative determination of trypsin, trypsin-like enzymes and enzyme inhibitors. Anal. Biochem. 2:370-379.

Corsini, D., J. Pavek, and B. Dean. 1992. Differences in free and protein-bound tyrosine among potato genotypes and their relationship to internal blackspot resistance. Amer. Potato J. 69:423-435.

Craft, C.C. 1966. Localization and activity of phenolase in the potato tuber. Amer. Potato J. 43:112-121.

Dean, B.B., N. Jackowiack, M. Nagle, J. Pavek, and D. Corsini. 1993. Blackspot pigment development of resistant and susceptible Solanum tuberosum L. genotypes at harvest and during storage measured by three methods of evaluation. Amer. Potato J. 70:201-217.

Dean, B.B., N. Jackowiack, and S. Munck. 1992. Tyrosine synthesis in potato tuber tissue from blackspot-susceptible and resistant genotypes. Potato Res. 35:49-53.

Gilchrist, D.G. and T. Kosuge. 1980. Aromatic amino acid biosynthesis and its regulation. In: B. J. Miflin (ed.). The Biochemistry of Plants. vol. 5. Academic Press, New York.

Gilchrist, D.G., T.S. Woodin, M.L. Johnson, and T. Kosuge. 1972. Regulation of aromatic amino acid biosynthesis in higher plants. Plant Physiol. 49:52-57.

Goers, S.K. and R.A. Jensen. 1984. Separation and characterization of two chorismatic-mutase isoenzymes from Nicotiana silvestris. Planta 162:109-116.

Hughes, J. C., J. E. Ayers, and T. Swain. 1962. After-cooking blackening in potatoes. I. Introduction and analytical methods. J. Sci. Food Agr. 13:224-229.

Jensen, R.A. 1986. Tyrosine and phenylalanine biosynthesis: Relationship between alterative pathways, regulation and subcellular location. In: E.E. Conn (ed.). Recent Advances in Enzymology 20:57-81. Plenum Press, New York.

Kunkel, R. and W.H. Gardner. 1965. Potato tuber hydration and its effect on blackspot of Russet Burbank potatoes in the Columbia Basin of Washington. Amer. Potato J. 42:109-124.

Kuroki, G.W. and E.E. Conn. 1988. Purification and characterization of an inducible aromatic amino acid-sensitive form of chorismate mutase from Solanum tuberosum L. tubers. Arch. of Biochem. and Biophysics 260:616-621.

Mapson, L.W., T. Swain, and A.W. Tomalin. 1963. Influence of variety, cultural conditions and temperature of storage on enzymatic browning of potato tubers. J. Sci. Food Agr. 14:673-684.

Matheis, G. 1987a. Polyphenol oxidase and enzymatic browning of potatoes (Solanum tuberosum). I. Properties of potato polyphenol oxidase. Chem. Mikrobiol. Technol. Lebensm. 11:5-12. 
Matheis, G. 1987b. Polyphenol oxidase and enzymatic browning of potatoes (Solanum tuberosum). II. Enzymatic browning and potato constituents. Chem. Mikrobiol. Technol. Lebensm. 11:33-41.

Mulder, E.G. 1949. Mineral nutrition in relation to the biochemistry and physiology of potatoes. Plant and Soil 2:59-121.

Patil, S.S. and J. Zucker. 1965. Potato phenolases, purification and properties. J. Biol. Chem. 240:3938-3943.

Pavek, J., C.R. Brown, M.W. Martin, and D.L. Corsini. 1993. Inheritance of blackspot bruise resistance in potato. Amer. Potato J. 70:43-48.

Santarius, K. and H.-D. Belitz. 1978. Proteinase activity in potato plants. Planta 141:145-153.

Sapers, G.M., F.W. Douglas Jr., A. Bilyk, A.-F. Hsu, H.W. Dover, L. Garzarella, and M. Kozempel. 1989. Enzymatic browning in Atlantic potatoes and related cultivars. J. Food Sci. 54:362-365.

Singh, B.K., Lonergan, S.G., and E.E. Conn. 1986. Chorismate mutase isoenzymes from selected plants and their immunological comparison with the isozymes from sorghum bicolor. Plant Physiol. 81:717-722.

Stark, J.C., D.L. Corsini, P.J. Hurley, and R.B. Dwelle. 1985. Biochemical characteristics of potato clones differing in blackspot susceptibility. Amer. Potato J. 62:657-666.

Tripathi, V.K., S.P. Jarn, H.B. Ran, and S. Singh. 1983. Studies on enzymatic and non-enzymatic discoloration in tubers of some potato varieties. Prog. Hort. 15:152-154.

Van Middelem, C.H., W.C. Jacob, and H.C. Thompson. 1953. Spectrophotometric comparison of internal blackspot and melanin. Amer. Potato J. 30:85-88.

Waters, S.P. and M.J. Dalling. 1979. Distribution and characteristics of aminoacyl -naphthylamidase activities in wheat seedlings. Austral. J. of Plant Physiol. 6:595-606.

Weaver, M.L., E. Hautala, and R.M. Reeve. 1970. Distribution of oxidase enzymes in potato tubers relative to blackspot susceptibility. I. Phenolases. Amer. Potato J. 47:479-488. 